ZEIST, AR; RESENDE, JTV; LIMA FILHO, RB; GABRIEL, A; HENSCHEL, JM; SILVA, IFL. 2019. Phenology and agronomic components of first and second-cycle strawberry. Horticultura Brasileira 37:029-034 DOI - http://dx.doi.org/10.1590/S0102-053620190104

\title{
Phenology and agronomic components of first and second-cycle strawberry
}

\author{
André R Zeist ${ }^{1} \mathbb{D}$; Juliano TV de Resende ${ }^{2} \mathbb{D}$; Renato B Lima Filho ${ }^{3} \mathbb{D}$; André Gabriel ${ }^{3} \mathbb{D}$; Juliane $M$ \\ Henschel ${ }^{4} \mathbb{D}$; Israel FL da Silva ${ }^{3 \mathbb{D}}$
}

${ }^{1}$ Universidade do Oeste Paulista (UNOESTE), Presidente Prudente-SP, Brazil; andre.zeist@bol.com.br; andre.gb85@hotmail.com; ${ }^{2}$ Universidade Estadual de Londrina, Londrina-PR, Brazil; jvresende@uol.com.br; ${ }^{3}$ Universidade Estadual do Centro-Oeste (UNICENTRO), Guarapuava-PR, Brazil; delimafilho.renato@yahoo.com; israel.felipe30@gmail.com; ${ }^{4}$ Universidade Federal de Viçosa (UFV), Viçosa-MG, Brazil; julianemhenschel@gmail.com

\begin{abstract}
Several strawberry growers have cultivated the same plants for two consecutive cycles aiming a greater economic return after seedling transplant. However, the phenological development and the agronomic potential of second-cycle strawberry have to be estimated. This research was installed to estimate the thermal need, leaf appearance rate, phyllochron and yield of strawberry cultivars in two consecutive crop cycles in the region of the Third Planalto Paranaense. Cultivars Camarosa, Camino Real, Albion, Aromas, Monterrey and San Andreas were evaluated in the first and second growing cycles using completely randomized blocks and four replications. Leaf appearance rate was estimated by linear regression coefficient between the number of leaves and the accumulated thermal sum. Phyllochron was estimated by the inverse of regression coefficient. Aromas was the only cultivar with an increased fruit production in the second cycle. On the contrary, there was a considerable reduction of production for 'Camino Real', 'Albion', 'Monterrey' and 'San Andreas' in that same cycle. The highest number and mass of marketable fruits of the second and first cycles were observed for 'Camarosa' and 'Camino Real', respectively. In the second crop cycle, strawberry cultivars required a lower thermal sum to begin flowering and fruit harvest. The plants presented a higher leaf appearance rate and low phyllochron values.
\end{abstract}

Keywords: Fragaria x ananassa, leaves emission, phyllochron, fruit production, thermal sum.

\section{RESUMO}

Fenologia e componentes agronômicos de morangueiros de primeiro e segundo ciclo

Em busca de maior retorno econômico após o transplantio das mudas, muitos produtores de morango têm feito o cultivo por dois ciclos consecutivos. No entanto, há necessidade de estimar o desenvolvimento fenológico e avaliar o potencial agronômico do morangueiro nesse sistema. $\mathrm{O}$ objetivo deste trabalho foi comparar a necessidade térmica, a taxa de aparecimento foliar, o filocrono e a produtividade de cultivares de morangueiro no segundo ciclo de cultivo, em comparação ao primeiro, na região do Terceiro Planalto Paranaense. Avaliaram-se as cultivares Camarosa, Camino Real, Albion, Aromas, Monterrey e San Andreas, utilizando o delineamento experimental de blocos ao acaso e com quatro repetições. A taxa de aparecimento foliar foi estimada a partir do coeficiente angular da regressão linear entre o número de folhas e a soma térmica acumulada, enquanto o filocrono foi estimado pelo inverso do coeficiente angular da regressão. Observou-se que Aromas foi a única cultivar que aumentou a produção de frutos no segundo ciclo. Ao contrário, nesse mesmo ciclo houve considerável redução da produção para 'Camino Real', 'Albion', 'Monterrey' e 'San Andreas'. Destacaram-se com maior número e massa de frutos comerciais do segundo e primeiro ciclo, 'Camarosa' e 'Camino Real', respectivamente. No segundo ciclo de cultivo, as cultivares de morangueiro necessitaram menor soma térmica acumulada para iniciar o florescimento e colheita dos frutos e, apresentaram maior taxa de aparecimento foliar e menores valores de filocrono.

Palavras-chave: Fragaria x ananassa, emissão de folhas, filocrono, produção, soma térmica.

\section{Received on November 15, 2017; accepted on September 14, 2018}

$\mathrm{S}^{\mathrm{s}}$ trawberry (Fragaria $\mathrm{x}$ ananassa) is cultivated in a wide geographic distribution due to its ability to adapt to different soil and climatic conditions (Morales et al., 2012). This small fruit is the most widely cultivated and consumed fruit in the world (Tazzo et al., 2015). In Brazil, it is mainly produced in small rural properties. In recent years, there has been a considerable increase in its production (Witter et al., 2012).
The main strawberry cultivars in Brazil derive from genetic improvement programs conducted in the United States, with emphasis on 'Oso Grande', 'Camarosa', 'Aromas', 'Diamante', 'Camino Real', 'Albion', Monterey', 'San Andreas', 'Palomar' and 'Portola', developed at the University of California; 'Dover', 'Sweet Charlie' and 'Florida Festival', were developed at the University of Florida. These materials should be evaluated on productivity, quality, growth and vegetative development (Tazzo et al., 2015).

Aiming greater economic returns after seedling transplanting, many strawberry producers have cultivated the same plants for two or more consecutive cycles. Family farmers in the municipality of GuarapuavaPR, located in the region of the Third Planalto Paranaense, have reported 
that production is lower in the second production cycle than in the first one. However, fruits are produced earlier, thus guaranteeing a high market value. In that municipality, approximately 60 tons of strawberry were harvested in 2017, amounting approximately $\mathrm{R} \$ 900,000$. However, there is yet no scientific information on the productive potential of strawberry in the second cycle compared to the first one.

The knowledge on the phenological behavior of a particular plant species or cultivar is of extreme importance since it is a tool for forecasting events and making decisions regarding crop management (Pereira et al., 2010; Tomazetti et al., 2015). Among the factors closely related to changes in phenological stages, temperature is the most relevant. It results in thermal energy and drives vegetative development and growth (Liu \& Heins, 2002). In firstcycle strawberry plants, there is a close relationship between temperature and vegetative canopy formation (Mendonça et al., 2012a,b,c; Tazzo et al., 2015). However, similar to the productive potential, second-cycle plants may present a different developmental response to air temperature.

A biologically realistic measurement for estimating growth and development regarding air temperature is the thermal sum $\left({ }^{\circ} \mathrm{C}\right.$ days) (Streck et al., 2008; Heldwein et al., 2010; Lucas et al., 2012). It has a greater meaning regarding plants than calendar days. Based on the thermal sum, it is possible to estimate the number of leaves in strawberry by means of phyllochron $\left({ }^{\circ} \mathrm{C}\right.$ day leaf $\left.{ }^{-1}\right)$, which is the time interval between the appearance of two successive leaves in the main canopy (Xue et al., 2004; Streck et al., 2005).

Studies using the phyllochron concept have been carried out on several agricultural species, such as barley and wheat (Xue et al., 2004), safflower (Streck et al., 2005), lettuce (Hermes et al., 2001), eucalyptus (Martins et $a l ., 2007)$ and tomato (Pivetta et al., 2007). Regarding strawberry, Tazzo et al. (2015) evaluated the phyllochron in two selections ('SEL1' and 'SEL2') and in the cultivars Camino Real, Camarosa, San Andreas and Albion. The authors verified that there was variability among them, with a lower phyllochron value for selection $1\left(69.96^{\circ}\right.$ day leaf $\left.{ }^{1}\right)$ and a higher value for the Albion cultivar $\left(135.61^{\circ}\right.$ day leaf ${ }^{-1}$ ). Mendonça et al. (2012a) verified a variation in phyllochron values among strawberry cultivars in strawberry intercropped with fig trees and in single crop.

Although there is information on phyllochron for strawberry cultivars, it is necessary to identify their phenological performance at the site of cultivation (Tazzo et al., 2015). In addition, there is a need to determine the growth, development and agronomic potential of second-cycle strawberry. Considering the aforementioned information, the objective of this study is to estimate thermal needs, leaf emission rate, phyllochron and yield of strawberry cultivars in second crop cycle in comparison to the first cycle in the Terceiro Planalto region of Paraná.

\section{MATERIAL AND METHODS}

The experiments were conducted at the Center for Research on Vegetables of the Department of Agronomy of the State University of the CenterWest (UNICENTRO) located in the municipality of Guarapuava, Paraná (253' $\mathrm{S}, 51^{\circ} 48^{\prime} \mathrm{W}, 1,100$ meters altitude). This region belongs to the Third Planalto Paranaense. The climate, according to Köppen's classification, is $\mathrm{Cfb}$ (humid mesothermic subtropical), temperate, with no defined dry season, hot summers and moderate winters (Wrege et al., 2011). The soil is classified as typical dystroferric Bruno Latosol (Embrapa, 2013).

The strawberry cultivars Camarosa, Camino Real (short-day cultivars), Albion, Aromas, Monterrey and San Andreas (neutral day cultivars) were evaluated in the second and first cycles in 2014. The experimental design was randomized blocks with four replications, with each plot consisting of twelve useful plants. The two crop cycles were studied in individualized experiments.

Second-cycle plants were commercial seedlings imported from
Chile in 2013, certified and diseases free, cultivated during the 2013-2014 harvest. Seedlings were kept in the same place of cultivation of the previous cycle in 2014, in a low tunnel. They were managed according to climatic elements, subjected to removal of all leaves (toilet) on June 20, 2014, and then used to conduct one of the experiments. The first-cycle plants were commercial seedlings imported from Chile in 2014, and transplanted to the field at the beginning of July in order to conduct the other experiment.

The cultivars of both cycles were planted in a $0.8 \mathrm{~m}$-high tunnel system, covered with a transparent 75-micra low-density polyethylene film (LDPE), on beds $1.0 \mathrm{~m}$ wide and $0.25 \mathrm{~m}$ high, covered with a 50-micra black polyethylene film. Plants were arranged in a quincunx, on 30x30 cm spacing.

Based on chemical analysis, the soil was corrected three months before transplanting by applying $50.0 \mathrm{~g}$ per $\mathrm{m}^{2}$ of dolomitic limestone (75\% PRNT), in order to reach $80 \%$ base saturation. At the moment of transplanting the first-cycle and pruning second-cycle leaves, $200 \mathrm{~g}$ single superphosphate, $25 \mathrm{~g}$ potassium chloride, $25 \mathrm{~g}$ urea and $2.5 \mathrm{~kg}$ cattle manure were applied on the surface of each plot and incorporated into the soil, as recommended by Henschel et al. (2017).

Phytosanitary control was performed using preventive sprays of commercial products containing thiamethoxam (Actara) and azoxystrobin + diphenoconazole (Amistar Top) according to technical manufacturer recommendations. Irrigation was performed by micro-drips according to practical observations of crop's water requirement.

During the experimental periods, daily data of minimum (Tn) and maximum (Tx) air temperatures were collected at the automatic meteorological station of the CenterWest State University, located $120 \mathrm{~m}$ from the experiment. In second-cycle plants, the number of leaves (NL) of each plant was counted after thinning. For the first cycle, NL count was performed after leaf emission. A leaf is new when it is at least $1 \mathrm{~cm}$ long. The 
NL count was performed every five days until the beginning of fruit harvest. During the cycle, the time when plants started flowering was also recorded. It was defined when $50 \%$ of the plants had at least one inflorescence per plant. The beginning of the harvest was defined when at least $50 \%$ of plants had at least one fruit at harvest stage.

The fruits were harvested at a maturation stage with $2 / 3$ red staining. They were evaluated in their production components: number of marketable fruits $\left(\mathrm{NCF}\right.$, plant fruit $\left.{ }^{-1}\right)$, total number of fruits (TNF, plant fruits ${ }^{-1}$ ), mass of marketable fruits (MCF, g plant ${ }^{-1}$ ) and total fruit mass per plant (TFM, g plant ${ }^{-1}$ ). Fruits were considered marketable with a mass greater than 10 $\mathrm{g}$ without defects (wilted, deteriorated, malformed, mechanically damaged or attacked by diseases or pests).

The daily thermal sum $\left(\mathrm{TSd},{ }^{\circ} \mathrm{C}\right.$ day) was calculated as proposed by Arnold (1960): TSd $=(\mathrm{Tm}-\mathrm{Tb}) * 1$ day (1). The mean air temperature (Tm) was determined by the arithmetic average between $\mathrm{Tn}$ and $\mathrm{Tx}$ of the air. $\mathrm{Tb}$ is the base temperature for strawberry leaf emission, below which there is no emission of new leaf structures. The adopted $\mathrm{Tb}$ was $7.0^{\circ} \mathrm{C}$ (Mendonça et al., 2012a; Tazzo et al., 2015). The accumulated thermal sum $\left(\mathrm{TSa},{ }^{\circ} \mathrm{C}\right.$ day) was defined by summing the daily values $(\mathrm{TSa}=\Sigma \mathrm{TSd})$. The leaf appearance rate (LAR, leaf ${ }^{\circ} \mathrm{C}$ day ${ }^{-1}$ ) was estimated using linear regression coefficient between the NL and the accumulated thermal sum $\left(\mathrm{TSa},{ }^{\circ} \mathrm{C}\right.$ day). The phyllochron $\left({ }^{\circ} \mathrm{C}\right.$ day leaf $\left.{ }^{-1}\right)$ of each plant was estimated by the inverse of the linear regression coefficient between NL and TSa (Streck et al., 2005; Martins et al., 2007; Pivetta et al., 2007).

The data of the evaluated characteristics were tested for normality and homogeneity of residual variances by Lilliefors \& Bartlett tests, respectively, and later submitted to analysis of variance, individually and combining both experiments. When the $F$ test was significant, means were submitted to comparison by Tukey test at $5 \%$ probability and analyzed using the ASSISTAT software, version 7.7 (Silva \& Azevedo, 2016).

\section{RESULTS AND DISCUSSION}

Due to the significant interaction between cycles and genotypes, results will be presented separately.

During the observation periods (June to October 2014) for second-cycle strawberry cultivars, the minimum temperature values $(\mathrm{Tn})$ ranged from $-2.0^{\circ} \mathrm{C}$ (July $1^{\text {st }}$ ) to $15.6^{\circ} \mathrm{C}$ (September $\left.2^{\text {nd }}\right)$ and the maximum temperatures (Tx) ranged from $11.0^{\circ} \mathrm{C}$ (July $25^{\text {th }}$ ) to $27.2^{\circ} \mathrm{C}$ (August $24^{\text {th }}$ ). For average air temperatures $(\mathrm{Tm})$, the range was from $8.0^{\circ} \mathrm{C}$ (July $1^{\text {st }}$ ) to $20.0^{\circ} \mathrm{C}$ (August $\left.24^{\text {th }}\right)$. For first-cycle plants, Tn values ranged from $-2.0^{\circ} \mathrm{C}$ (July $1^{\text {st }}$ ) to $19.2^{\circ} \mathrm{C}$
(October $15^{\text {th }}$ ), Tx ranged from $11.0^{\circ} \mathrm{C}$ (July $25^{\text {th }}$ ) to $33.6^{\circ} \mathrm{C}$ (October $\left.17^{\text {th }}\right)$, and Tn values ranged from $8.0^{\circ} \mathrm{C}$ (July $1^{\text {st }}$ ) to $25.0^{\circ} \mathrm{C}\left(\right.$ October $\left.10^{\text {th }}\right)$. During the observations, there was an incidence of minimum temperatures below the base temperature $\left(7.0^{\circ} \mathrm{C}\right)$ at 14 and 12 days for second and first-cycle plants, respectively (Figure 1).

The values of daily thermal sum (TSd) for cultivars in the second cycle ranged from 1 to $13^{\circ} \mathrm{C}$ day. In the first cycle, values ranged from 1 to $18^{\circ} \mathrm{C}$ day. The beginning of flowering of all cultivars in the second cycle occurred with an accumulated thermal sum (TSa) of $188.8^{\circ} \mathrm{C}$ day, lower than the first cycle, which was $381.9^{\circ} \mathrm{C}$ day for short-day cultivars and $316.4^{\circ} \mathrm{C}$ for neutral-day cultivars (Table 1).

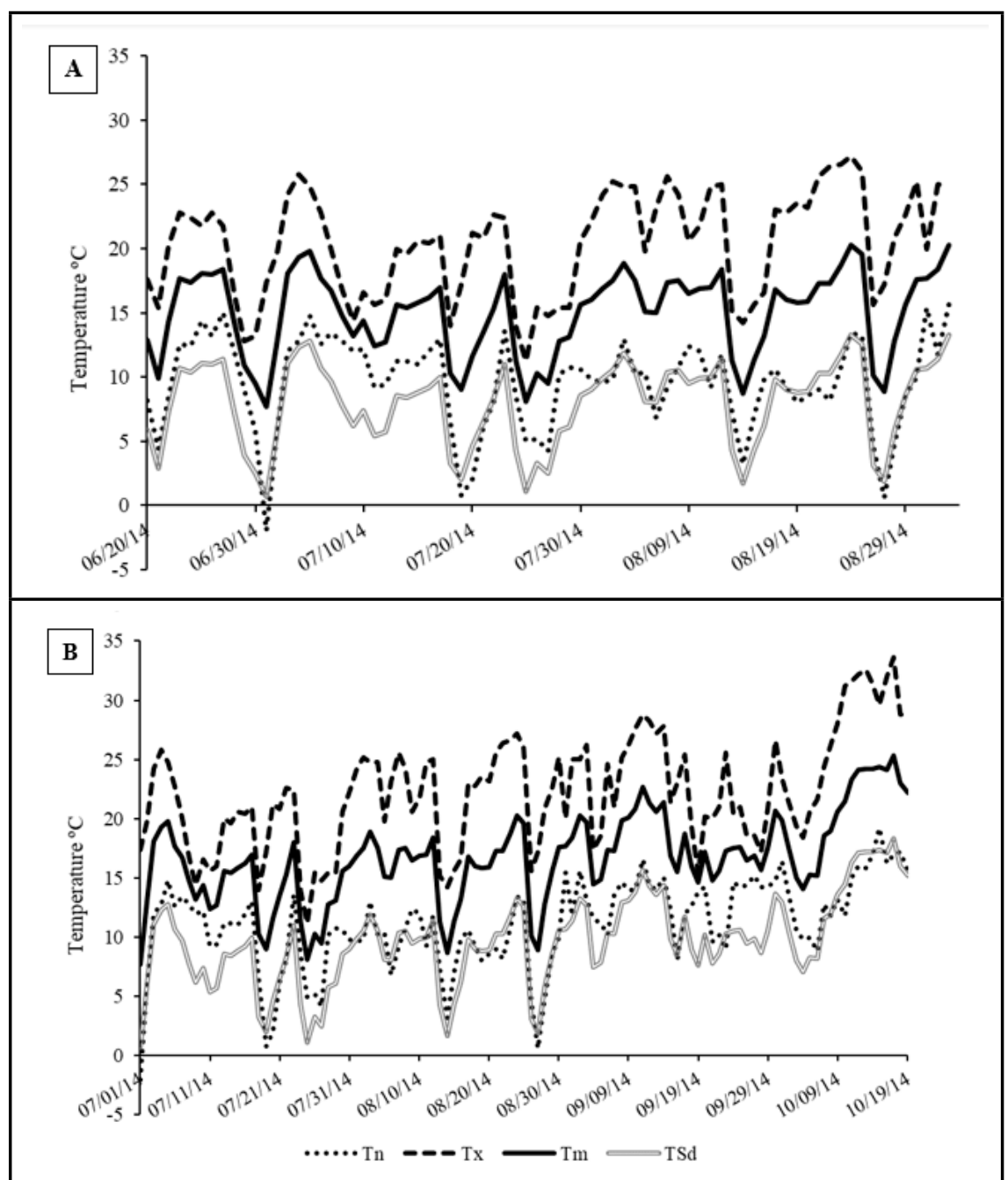

Figure 1. Minimum $\left(\mathrm{Tn},{ }^{\circ} \mathrm{C}\right)$, maximum $\left(\mathrm{Tx},{ }^{\circ} \mathrm{C}\right)$ and average air temperatures $\left(\mathrm{Tm},{ }^{\circ} \mathrm{C}\right)$ and daily thermal sum (TSd, ${ }^{\circ} \mathrm{C}$ day) during the periods considered to estimate phyllochron in strawberry cultivars of second (A) and first (B) cycles in the Third Planalto Paranaense region. Guarapuava, UNICENTRO, 2014. 
Table 1. Phenological cycle of defoliation/transplanting at the beginning of flowering (D/T - Fl) and defoliation/transplanting at the beginning of fruit harvest (D/T - BFH) of strawberry cultivars of second and first cycles in the Third Planalto Paranaense region. Guarapuava, UNICENTRO, 2014.

\begin{tabular}{|c|c|c|c|}
\hline \multirow{2}{*}{ Genotype } & \multicolumn{3}{|c|}{ Second cycle } \\
\hline & Defoliation & D - FI (TSd) & D - BFH (TSd) \\
\hline Camarosa & $06 / 20 / 2014$ & $07 / 13 / 2014\left(188.8^{\circ} \mathrm{C}\right.$ day $)$ & $09 / 02 / 2014\left(598.5^{\circ} \mathrm{C}\right.$ day $)$ \\
\hline Camino Real & $06 / 20 / 2014$ & $07 / 13 / 2014\left(188.8^{\circ} \mathrm{C}\right.$ day $)$ & $09 / 02 / 2014\left(598.5^{\circ} \mathrm{C}\right.$ day $)$ \\
\hline Albion & $06 / 20 / 2014$ & $07 / 13 / 2014\left(188.8^{\circ} \mathrm{C}\right.$ day $)$ & $09 / 02 / 2014\left(598.5^{\circ} \mathrm{C}\right.$ day $)$ \\
\hline Aromas & $06 / 20 / 2014$ & $07 / 13 / 2014\left(188.8^{\circ} \mathrm{C}\right.$ day $)$ & 09/02/2014 (598.5 $5^{\circ} \mathrm{C}$ day $)$ \\
\hline Monterrey & $06 / 20 / 2014$ & $07 / 13 / 2014\left(188.8^{\circ} \mathrm{C}\right.$ day $)$ & $09 / 02 / 2014\left(598.5^{\circ} \mathrm{C}\right.$ day $)$ \\
\hline \multirow[t]{3}{*}{ San Andreas } & $06 / 20 / 2014$ & $07 / 13 / 2014\left(188.8^{\circ} \mathrm{C}\right.$ day $)$ & 09/02/2014 (598.5 ${ }^{\circ} \mathrm{C}$ day $)$ \\
\hline & \multicolumn{3}{|c|}{$\begin{array}{ll}\text { First cycle } \\
\end{array}$} \\
\hline & Transplanting & T - Fl (TSd) & T - BFH (TSd) \\
\hline Camarosa & $07 / 01 / 2014$ & $08 / 19 / 2014\left(381.9^{\circ} \mathrm{C}\right.$ day $)$ & $10 / 19 / 2014\left(1,076.5^{\circ} \mathrm{C}\right.$ day $)$ \\
\hline Camino Real & 07/01/2014 & $08 / 19 / 2014\left(381.9^{\circ} \mathrm{C}\right.$ day $)$ & $10 / 17 / 2014\left(1,045.3^{\circ} \mathrm{C}\right.$ day $)$ \\
\hline Albion & 07/01/2014 & $08 / 10 / 2014\left(316.4^{\circ} \mathrm{C}\right.$ day $)$ & $10 / 12 / 2014\left(961.9^{\circ} \mathrm{C}\right.$ day $)$ \\
\hline Aromas & $07 / 01 / 2014$ & $08 / 10 / 2014\left(316.4^{\circ} \mathrm{C}\right.$ day $)$ & $10 / 12 / 2014\left(961.9^{\circ} \mathrm{C}\right.$ day $)$ \\
\hline Monterrey & 07/01/2014 & $08 / 10 / 2014\left(316.4^{\circ} \mathrm{C}\right.$ day $)$ & $10 / 12 / 2014\left(961.9^{\circ} \mathrm{C}\right.$ day $)$ \\
\hline San Andreas & $07 / 01 / 2014$ & $08 / 10 / 2014\left(316.4^{\circ} \mathrm{C}\right.$ day $)$ & $10 / 06 / 2014\left(873.0^{\circ} \mathrm{C}\right.$ day $)$ \\
\hline
\end{tabular}

Table 2. Leaf appearance rate (LAR), phyllochron and coefficient of determination $\left(\mathrm{R}^{2}\right)$ of linear regressions between the number of leaves and the accumulated thermal sum of strawberry cultivars of second and first cycles in the Third Planalto Paranaense region. Guarapuava, UNICENTRO, 2014.

\begin{tabular}{|c|c|c|c|c|c|c|}
\hline \multirow{2}{*}{ Genotype } & \multicolumn{2}{|c|}{ LAR (leaf'C day $\left.^{-1}\right)$} & \multicolumn{2}{|c|}{ Phyllochron $\left({ }^{\circ} \mathrm{C}\right.$ day leaf $\left.{ }^{-1}\right)$} & \multicolumn{2}{|c|}{$\mathbf{R}^{2}$} \\
\hline & Second & First & Second & First & Second & First \\
\hline Camarosa & $0.0244 \mathrm{Ab}^{*}$ & $0.0085 \mathrm{Babc}$ & $41.0 \mathrm{Bb}^{*}$ & $117.9 \mathrm{Ac}$ & 0.95 & 0.96 \\
\hline Camino Real & $0.0171 \mathrm{Ac}$ & $0.0084 \mathrm{Babc}$ & $58.6 \mathrm{Ba}$ & $120.0 \mathrm{Ac}$ & 0.95 & 0.96 \\
\hline Albion & $0.0163 \mathrm{Ac}$ & $0.0070 \mathrm{Bbc}$ & $61.3 \mathrm{Ba}$ & $142.4 \mathrm{Ab}$ & 0.95 & 0.97 \\
\hline Aromas & $0.0241 \mathrm{Ab}$ & $0.0109 \mathrm{Ba}$ & $41.8 \mathrm{Bb}$ & $91.8 \mathrm{Ae}$ & 0.95 & 0.96 \\
\hline Monterrey & $0.0326 \mathrm{Aa}$ & $0.0062 \mathrm{Bc}$ & $31.0 \mathrm{Bc}$ & $160.8 \mathrm{Aa}$ & 0.93 & 0.94 \\
\hline San Andreas & $0.0155 \mathrm{Ac}$ & $0.0097 \mathrm{Ba}$ & $66.8 \mathrm{Ba}$ & $103.5 \mathrm{Ad}$ & 0.96 & 0.97 \\
\hline CV (\%) & \multicolumn{2}{|c|}{8.7} & \multicolumn{2}{|c|}{5.1} & \multicolumn{2}{|c|}{ - } \\
\hline
\end{tabular}

*Means followed by different uppercase letters on lines and different lowercase letters in columns differ by Tukey test, $<5 \%$ probability.

Due to the early flowering of secondcycle cultivars, the beginning of fruit harvest was also anticipated, beginning when TSa reached $598.5^{\circ} \mathrm{C}$ day. In the first cycle, a higher TSa was required to reach the fruit harvest point. The thermal accumulation for the cultivar San Andreas was $873.0^{\circ} \mathrm{C}$ day, for Albion, Aromas and Monterrey was $961.9^{\circ} \mathrm{C}$ day, for Camino Real was $1,045.3^{\circ} \mathrm{C}$ day, and for Camarosa was $1,076.5^{\circ} \mathrm{C}$ day (Table 1).

The TSa values of this work for the beginning of flowering and harvesting of first-cycle fruits are close to those observed by Tazzo et al. (2015) for the cultivars Camino Real, Camarosa, San Andreas and Albion. This demonstrates that the thermal sum is a realistic measurement to estimate the growth and development of strawberry from a biological point of view.

Among the cultivars in the first cycle, there was variation of TSa needs to start the flowering and maturation of fruits (Table 1).This indicates that the phenological behavior based on thermal energy should also be taken into account in the choice of cultivars to be planted in a given geographic region. The knowledge on the response of phenological stages enables the prediction of management activities and the scheduling of the harvest period of strawberry fruits (Tazzo et al., 2015).

The regressions between the number of leaves (NL) and TSa carried out to obtain leaf appearance rate (LAR) and phyllochron estimates showed a close relation $\left(R^{2} \geq 0.93\right)$ for combinations (cultivars $x$ cycles) (Table 2 ). $R^{2} \geq 0.93$ values indicate the existence of linearity between NL and TSa. The values also indicated that air temperature is an abiotic element highly related to the appearance of leaves in strawberry cultivars. This corroborates with the studies by Mendonça et al. (2012a) and 
Tazzo et al.(2015).

By comparing second-cycle cultivars, Monterrey presented the highest LAR $\left(0.0326\right.$ leaf ${ }^{\circ} \mathrm{C}$ day $\left.^{-1}\right)$ and the lowest phyllochron $\left(31.0^{\circ} \mathrm{C}\right.$ day leaf $\left.{ }^{1}\right)$. For the same cycle, cultivars Camino Real, Albion and San Andreas presented the lowest values of LAR and the highest values of phyllochron. In the first cycle, Monterrey had the lowest LAR $(0.0062$ leaf ${ }^{\circ} \mathrm{C}$ day $\left.^{-1}\right)$, without differing from Camarosa, Camino Real and Albion. It also had the highest phyllochron $\left(160.8^{\circ} \mathrm{C}\right.$ day leaf $\left.{ }^{-1}\right)$. Cultivars Aromas and San Andreas had the highest LAR, without differing from Camarosa and Camino Real. Aromas obtained the lowest phyllochron (Table 2).

There was a higher LAR and a lower phyllochron for all cultivars in the second cycle (Table 2). If LAR is high and phyllochron is low, plants should have a greater efficiency for emission of leaves in function of air temperature. Higher LAR, lower phyllochron and anticipation of flowering start and harvest of fruits, of plants managed in the second cycle, possibly are due to the

Table 3. Total number of fruits (TNF), total fruit mass (TFM), number of marketable fruits (NCF) and mass of marketable fruits (MCF) of strawberry cultivars of second and first cycles in the Third Planalto Paranaense region. Guarapuava, UNICENTRO, 2014.

\begin{tabular}{|c|c|c|c|c|}
\hline \multirow{2}{*}{ Genotype } & \multicolumn{2}{|c|}{ TNF (plant fruits ${ }^{-1}$ ) } & \multicolumn{2}{|c|}{ TFM $\left(\right.$ g plant $\left.^{-1}\right)$} \\
\hline & Second & First & Second & First \\
\hline Camarosa & $82.6 \mathrm{Aa}$ & 99.32Aab & $719.2 \mathrm{Aa}$ & $773.3 \mathrm{Ac}$ \\
\hline Camino Real & $49.3 \mathrm{Bbc}$ & $112.3 \mathrm{Aa}$ & $414.1 \mathrm{Bc}$ & $1012.7 \mathrm{Aa}$ \\
\hline Albion & $19.5 \mathrm{Bc}$ & $83.3 \mathrm{Ab}$ & $166.3 \mathrm{Bd}$ & $882.7 \mathrm{Ab}$ \\
\hline Aromas & $74.3 \mathrm{Aa}$ & $49.7 \mathrm{Bc}$ & $621.6 \mathrm{Ab}$ & $354.0 \mathrm{Bd}$ \\
\hline Monterrey & $59.1 \mathrm{Bb}$ & 95.0 Aab & $571.4 \mathrm{Bbc}$ & $777.6 \mathrm{Ac}$ \\
\hline San Andreas & $57.3 \mathrm{Bb}$ & 101.0 Aab & $444.2 \mathrm{Bc}$ & $768.1 \mathrm{Ac}$ \\
\hline \multirow[t]{3}{*}{ CV (\%) } & \multicolumn{2}{|c|}{17.3} & \multicolumn{2}{|c|}{19.7} \\
\hline & \multicolumn{2}{|c|}{ NCF (plant fruits ${ }^{-1}$ ) } & \multicolumn{2}{|c|}{ MCF $\left(\right.$ g plant $\left.^{-1}\right)$} \\
\hline & Second & First & Second & First \\
\hline Camarosa & $35.3 \mathrm{Aa}^{*}$ & $37.0 \mathrm{Ac}$ & $410.7 \mathrm{Aa}$ & $482.0 \mathrm{Ad}$ \\
\hline Camino Real & $20.4 \mathrm{Bb}$ & $66.7 \mathrm{Aa}$ & $218.3 \mathrm{Bc}$ & $907.0 \mathrm{Aa}$ \\
\hline Albion & $9.0 \mathrm{Bc}$ & 67.0 Aa & $105.0 \mathrm{Bd}$ & $784.3 \mathrm{Ab}$ \\
\hline Aromas & $30.9 \mathrm{Aa}$ & 13.7 Bd & $343.7 \mathrm{Ab}$ & $160.0 \mathrm{Be}$ \\
\hline Monterrey & $25.1 \mathrm{Bb}$ & $59.7 \mathrm{Ab}$ & $321.8 \mathrm{Bb}$ & $643.0 \mathrm{Ac}$ \\
\hline San Andreas & $21.5 \mathrm{Bb}$ & $57.3 \mathrm{Ab}$ & $226.6 \mathrm{Bc}$ & $622.8 \mathrm{Ac}$ \\
\hline $\mathrm{CV}(\%)$ & \multicolumn{2}{|c|}{16.2} & \multicolumn{2}{|c|}{18.5} \\
\hline
\end{tabular}

*Means followed by different uppercase letters on lines and different lowercase letters in columns differ by Tukey test, $<5 \%$ probability.

fact that plants presented a developed root system and were acclimatized to the environmental conditions after transplanting. On the other hand, firstcycle cultivars underwent stresses due to the transplant process and used the first assimilates for the growth and development of the root system. In addition, there were several lateral "canopies" in the second-cycle plants. Each canopy emitted several leaves. On the contrary, seedlings initially present a single canopy in first-cycle plants, which represents a low number of leaves, low LAR and a greater phyllochron.

Only cultivar Aromas showed a gain in production components in the second cycle compared to the first cycle. Camino Real, Albion, Monterrey and San Andreas presented higher total number of fruits (TNF), total fruit mass (TFM), number of marketable fruits (NCF) and mass of marketable fruits (MCF) in the first crop cycle (Table 3 ).

For Camarosa, there was no difference in production components between both crop cycles. When compared to the other cultivars, the

Hortic. bras., Brasília, v.37, n.1, January-March 2019 second-cycle Camarosa showed the highest TNF (82.6 fruits) (without differing from Aromas), the highest TFM (719.2 g) and NCF (35.3 fruits) (without differing from Aromas), and the highest MCF (410.7 g). In general, although Camarosa did not stand out for production components related to marketable fruits in the first cycle, it presented the highest potential to be cultivated for two consecutive cycles (Table 3).

In relation to the first cycle after transplanting, Camino Real obtained the highest TNF (112.3 fruits) (without differing from Camarosa, Monterrey and San Andreas), the highest TFM $(1,012.7 \mathrm{~g})$, the highest NCF (66.7 fruits) (without differing from Albion) and the highest MCF (907.0 g). However, when Camino Real was cultivated for the second consecutive cycle, it presented a decrease in TNF, TFM, NCF and MCF (Table 3): 43.9, 40.9, 30.6 and 24.0\%, respectively.

Although the cultivars Camino Real, Albion, Monterrey and San Andreas showed lower yields in the second cycle, compared to the first cycle, the use of second-cycle strawberry plants is an interesting alternative because it allows costs reduction in importation of seedlings, anticipation of fruit harvest and a greater market value. However, strawberry plants cultivated in second cycle present higher risk of pests and diseases incidence. The pruning of leaves in late fall is required, associated with preventive phytosanitary crop management.

Phenological components, in function of thermal sum calculated by the representation of biological time, are a widely used method. This method allows improving the prediction of dates of vegetative development stages (Zeist et al., 2017). Based on these components, the strawberry cultivars analyzed in this work, cultivated on the second consecutive cycle, require less thermal energy for emission of leaves, for flowering and for harvest. Such thermal values make it possible to stipulate the duration of development stages according to thermal conditions. It allows a better decision-making regarding the most appropriate 
management in two consecutive cycles of cultivation. However, depending on the strawberry cultivar, there is a considerable decrease in fruit production in the second crop cycle.

\section{REFERENCES}

ARNOLD, CY. 1960. Maximum-minimum temperature as a basis for computing heat units. Proceedings of the American Society for Horticultural Science 76: 682-692.

EMBRAPA - Empresa Brasileira de Pesquisa Agropecuária. 2013. Sistema brasileiro de classificação de solos. 3.ed. Rio de Janeiro: Embrapa Solos. 353p.

HELDWEIN, AB; STRECK, NA; STURZA, VS; LOOSE, LH; ZANON, AJ; TOEBE, M; SOUZA, AT; PETERS, MB; KARLEC, F. 2010. Plastocrono e rendimento de feijão-devagem cultivado sob ambiente protegido e no ambiente externo em semeadura tardia no outono. Ciência Rural 40: 768-773.

HENSCHEL, JM; RESENDE, JTV; GILONILIMA, PC; ZEIST, AR; LIMA FILHO, RB; SANTOS, MH. 2017. Production and quality of strawberry cultivated under different colors of low tunnel cover. Horticultura Brasileira 35: 364-370

HERMES, CC; MEDEIROS, SLP; MANFRON, PA; CARON, B; POMMER, SF; BIANCHI, CAM. 2001. Emissão de folhas de alface em função da soma térmica. Revista Brasileira de Agrometeorologia 9: 269-275.

LIU, B; HEINS, D. 2002. Photothermal ratio affects plant quality in 'Freedom' Poinsettia. Journal of the American Society for Horticultural Science 127: 20-26.

LUCAS, DDP; STRECK, NA; BORTOLUZZI, MP; TRENTIN, R; MALDANER, IC. 2012. Temperatura base para emissão de nós e plastocrono de plantas de melancia. Revista Ciência Agronômica 43: 288-292.

MARTINS, FB; SILVA, JC; STRECK, NA. 2007. Estimativa da temperatura-base para emissão de folhas e do filocrono em duas espécies de eucalipto na fase de muda. Revista Arvore 31: 373-381.

MENDONÇA, HFC; CALVETE, EO; NIENOW, AA; COSTA, RC; ZERBIELLI, L; BONAFÉ, M. 2012a. Estimativa do filocrono de morangueiro em sistemas consorciado e solteiro em ambientes protegidos. Revista Brasileira de Fruticultura 34: 15-23.

MENDONÇA, HFC; MÜLLER, AL; BOENO, MC; ZERBIELLI, L; BONAFÉ, M; TAZZO, IF; CALVETE, EO; NIENOW, AA. 2012b. The phyllochron of strawberry intercropped with fig trees in a greenhouse. Acta Horticulturae 926: 547-550.

MENDONÇA, HFC; MÜLLER, AL; TAZZO, IF; CALVETE, EO. 2012c. Accumulated leaf number in strawberry cultivars grown in a greenhouse. Acta Horticulturae 926: 295-300.

MORALES, RGF; FARIA, MV; RESENDE, JTV; RISSINI, ALL; CARMINATTI, R; FARIA, CMD. 2012. Produtividade do morangueiro em função da adubação orgânica complementar em cultivo protegido. Ambiência 8: 23-33.

PEREIRA, LC; CAMPELO JÚNIOR, JH; FERRONATO, A. 2010. Comparação de métodos para estimativa do plastocrono em algodoeiro em condições tropicais. Pesquisa Agropecuária Tropical 40: 213-220.

PIVETTA, CR; TAZZO, IF; MAASS, GF; STRECK, NA; HELDWEIN, AB. 2007. Emissão e expansão foliar em três genótipos de tomateiro (Lycopersicon esculentum Mill.). Ciência Rural 37: 1274-1280.

SILVA, FAS; AZEVEDO, CAV. 2016. The Assistat Software Version 7.7 and its use in the analysis of experimental data. African Journal of Agricultural Research 11: 3733-3740.

STRECK, NA; BELLÉ, RA; ROCHA, EK;
SCHUH, M. 2005. Estimating leaf appearance and phyllochron in safflower (Carthamus tinctorius L.). Ciência Rural 35:1448-1450.

STRECK, NA; PAULA, GM; CAMERA, C; MENEZES, NL; LAGO, I. 2008. Estimativa do plastocrono em cultivares de soja. Bragantia 67: 67-73.

TAZZO, IF; FAGHERAZZI, AF; LERIN, SK; AIKE, A; RUFATO, L. 2015. Exigência térmica de duas seleções e quatro cultivares de morangueiro cultivado no planalto catarinense. Revista Brasileira de Fruticultura 37: 550558.

TOMAZETTI, TC; ROSSAROLLA, MD; ZEIST, AR; GIACOBBO, CL; WELTER, LJ; ALBERTO, CM. 2015. Fenologia e acúmulo térmico em videiras viníferas na região da Fronteira Oeste do Rio Grande do Sul. Pesquisa Agropecuária Brasileira 50: 1033-1041.

WITTER, S; RADIN, B; LISBOA, BB; TEIXEIRA, JSG; BLOCHTEIN, B; IMPERATRIZ-FONSECA, VL. 2012. Desempenho de cultivares de morango submetidas a diferentes tipos de polinização em cultivo protegido. Pesquisa Agropecuária Brasileira 47: 58-65.

WREGE, MS; STEINMETZ, S; REISSER JUNIOR, C; ALMEIDA, IR. 2011. Atlas climático da Região Sul do Brasil: Estados do Paraná, Santa Catarina e Rio Grande do Sul. 1. Pelotas: Embrapa Clima Temperado; Colombo: Embrapa Florestas, 336p.

XUE, Q; WEISS, A; BAENZIGER, PS. 2004. Predicting leaf appearance in field-grown winter wheat: evaluating linear and non-linear models. Ecological Modelling 175: 261-270.

ZEIST, AR; TOMAZETTI, TC; ROSSAROLLA, MD; ALBERTO, CM; GIACOBBO, CL; WELTER, LJ. 2017. Plastochron index of 'Cabernet Sauvignon' and 'Chardonnay' grapevines in Fronteira Oeste, in the state of Rio Grande do Sul, Brazil. Pesquisa Agropecuária Brasileira 52: 244-251. 